\title{
BIOCHEMICAL CHANGES IN FORMING AND REGRESSING DECIDUOMA IN THE RAT UTERUS
}

\author{
J. C. WOOD AND V. L. BARLEY \\ Department of Zoology and Division of Obstetrics, \\ University of Oxford
}

(Received 19th Fanuary 1970)

\begin{abstract}
Summary. The activities of $\beta$-glucuronidase and acid cathepsin D remain at a low level while decidual tissue is forming in the rat uterus but increase markedly during the period of decidual regression. By contrast, acid and alkaline phosphatase rise during deciduomal formation but fall during regression. The importance of lysosomal enzymes in the breakdown of decidual tissue is discussed in relation to these results.
\end{abstract}

\section{INTRODUCTION}

The decidual tissue which is formed in response to trauma to the rat endometrium on Day 4 of pseudopregnancy provides a convenient model for the study of biochemical changes associated with egg implantation. The implanting blastocyst induces hyperplasia, hypertrophy and differentiation of the endometrial stromal cells, and artificial trauma stimulates a similar set of responses. Unpublished studies on rats in our colony have shown that there is a period of intense metabolic activity and a rapid increase in the size of the uterus associated with the differentiation of decidual tissue between Days 5 and 8 of pseudopregnancy. After Day 9, however, the deciduoma starts to break down. By Day 10, decidual tissue is already starting to separate from the myometrium. At first, regression is slow but, by Day 14, autolysis is very marked and by Day 18 , little, if any, decidual tissue remains.

The regression of the decidual mass, like the post-partum involution of the uterus, is one of the most spectacular examples of tissue breakdown occurring under normal physiological conditions. Woessner (1965) found that the fresh weight of the rat uterus fell ten-fold during the first 4 days post partum. He also showed that the activity of a number of uterine lysosomal enzymes (particularly acid cathepsin D and $\beta$-glucuronidase) increased during this post-partum period. The similarity of these two types of tissue breakdown suggests that lysosomal enzymes might also be involved in the regression of the deciduoma.

In order to investigate the rôle that lysosomes might play in the biochemical changes associated with formation and regression of decidual tissue, the activity of three lysosomal enzymes was studied in artificially induced deciduomata in the rat uterus. 


\section{MATERIALS AND METHODS}

Adult, female, Wistar rats were made pseudopregnant by stimulation of the cervix with a glass rod on the day of vaginal cornification. This day is subsequently referred to as Day 0 of pseudopregnancy. On Day 4, the endometrium of one horn was scratched along its length with a burred hypodermic needle, the other horn being left as a control. The rats were killed at intervals of 1 or 2 days during the rest of pseudopregnancy. The uterine horns were removed from the body and weighed. Decidual tissue was scraped from the treated horn and endometrial tissue from the control side. Tissues were homogenized with distilled water to rupture the lysosomal membranes. After centrifugation, enzyme activities were measured in the supernatant fluid.

The enzymes studied were acid phosphatase, $\beta$-glucuronidase and acid cathepsin D. Alkaline phosphatase, though not a lysosomal enzyme, was also assayed since it serves as a useful index of decidual cell formation (Finn \& McLaren, 1967). Acid and alkaline phosphatase activities were measured at pH 4.8 and 10.5 respectively, using a $p$-nitrophenol substrate (Sigma Technical Bulletin 104, 1964). The activity of $\beta$-glucuronidase was measured at $\mathrm{pH} 4.5$ as the rate of liberation of phenolphthalein from its glucuronide (Talalay, Fishman \& Huggins, 1946). Acid cathepsin D was determined by the method of Woessner \& Brewer (1963) as the rate of release of tyrosine from haemoglobin. All enzyme activities were expressed as $\mu$ moles of substrate changed/g fresh weight/hr.

In order to gain information about changes in the connective tissue matrix, a preliminary investigation of the concentration of total acidic mucopolysaccharides in decidual tissue was also undertaken. Following tissue digestion with papain, the mucopolysaccharides were precipitated with cetyl pyridinium chloride (Manley \& Mullinger, 1967), and reprecipitated with absolute ethanol from 2 M-magnesium chloride. Total uronic acids were measured by the carbazole reaction of Bitter \& Muir (1962). Soluble protein was measured by the method of Lowry, Rosebrough, Farr \& Randall (1951).

\section{RESULTS}

Following endometrial trauma, the fresh weight of the treated horn increased rapidly to a maximum value on Day 8 , fell slightly between Days 8 and 12, and fell rapidly after Day 12 (Text-fig. 1). On the control side, the weight of the uterus fell slightly between Days 5 and 7 , after which it rose to reach a maximum weight on Day 12.

Text-figure 2 shows that on Days 5,6 and 7, the protein concentration in the decidual tissue was less than that in the endometrium of the control side. From Day 8 onwards, the protein concentrations in the deciduoma and in the control endometrium were not significantly different from each other.

There was an early rapid rise in alkaline phosphatase activity which reached a maximum of ten times the activity of the control side on Day 7 (Text-fig. 3). The activity in the decidual tissue then fell almost as rapidly and, by Day 12, had reached a level below that found on Day 5 . 


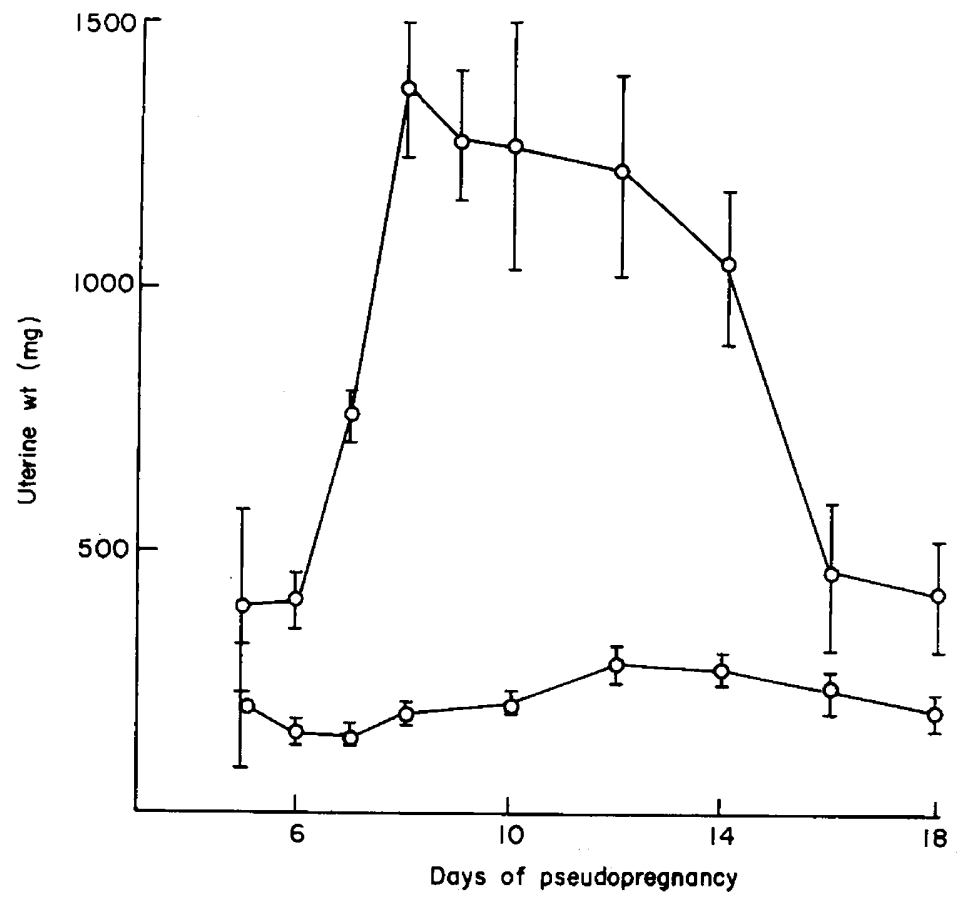

TEXT-FIG. 1. Ghange in uterine weight between Days 5 and 18 of pseudopregnancy. The lower line represents the control horn and the upper line shows the effect of uterine trauma. Each vertical bar represents \pm 1 S.E.M.

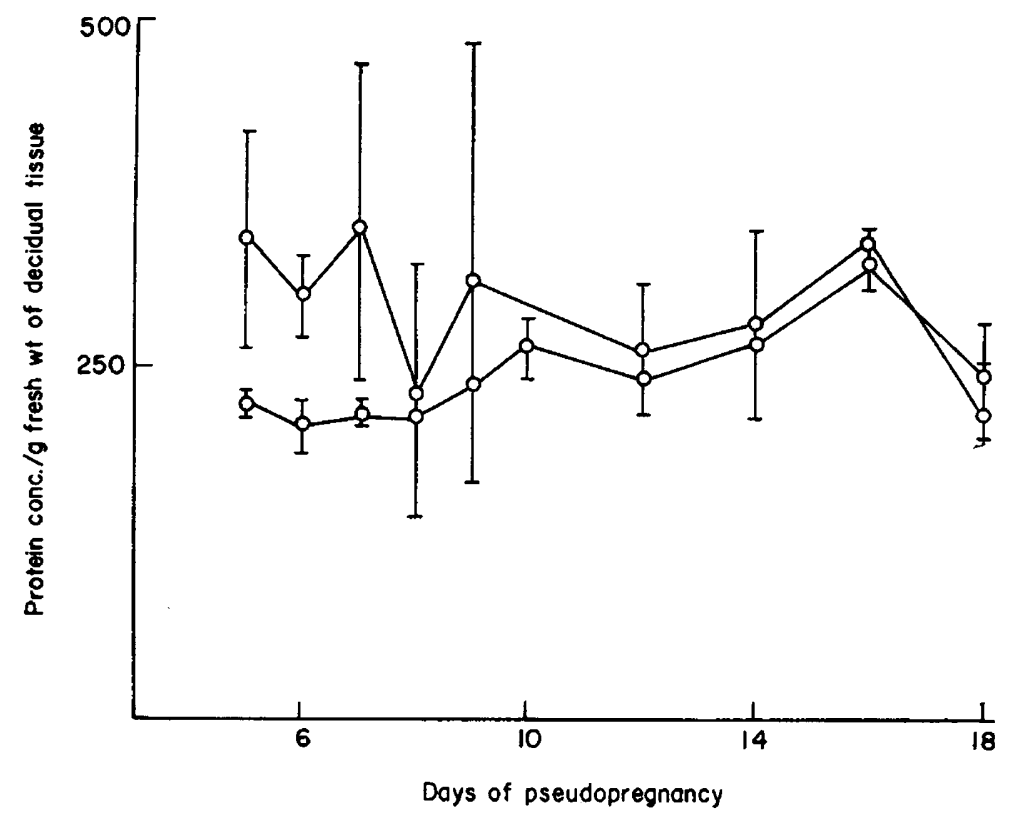

TEXT-FIG. 2. Change in protein concentration of decidual tissue between Days 5 and 18 of pseudopregnancy. The upper line represents the endometrium of the control horn and the lower line shows the effect of uterine trauma. Each vertical bar represents \pm 1 S.E.M. 


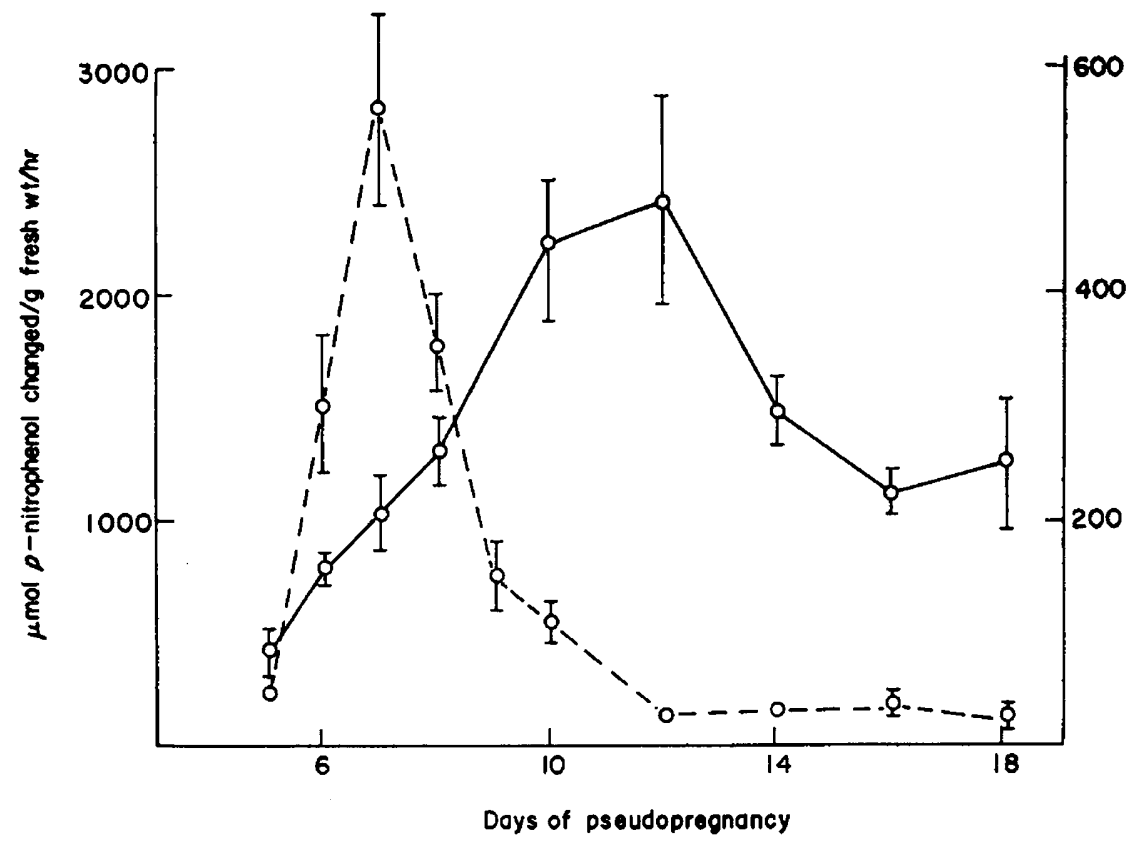

Text-Fig. 3. Changes in the activity of acid and alkaline phosphatase following uterine trauma during pseudopregnancy. The left ordinate gives values for alkaline phosphatase, the right ordinate gives values for acid phosphatase activity. Acid phosphatase

Alkaline phosphatase - - - .

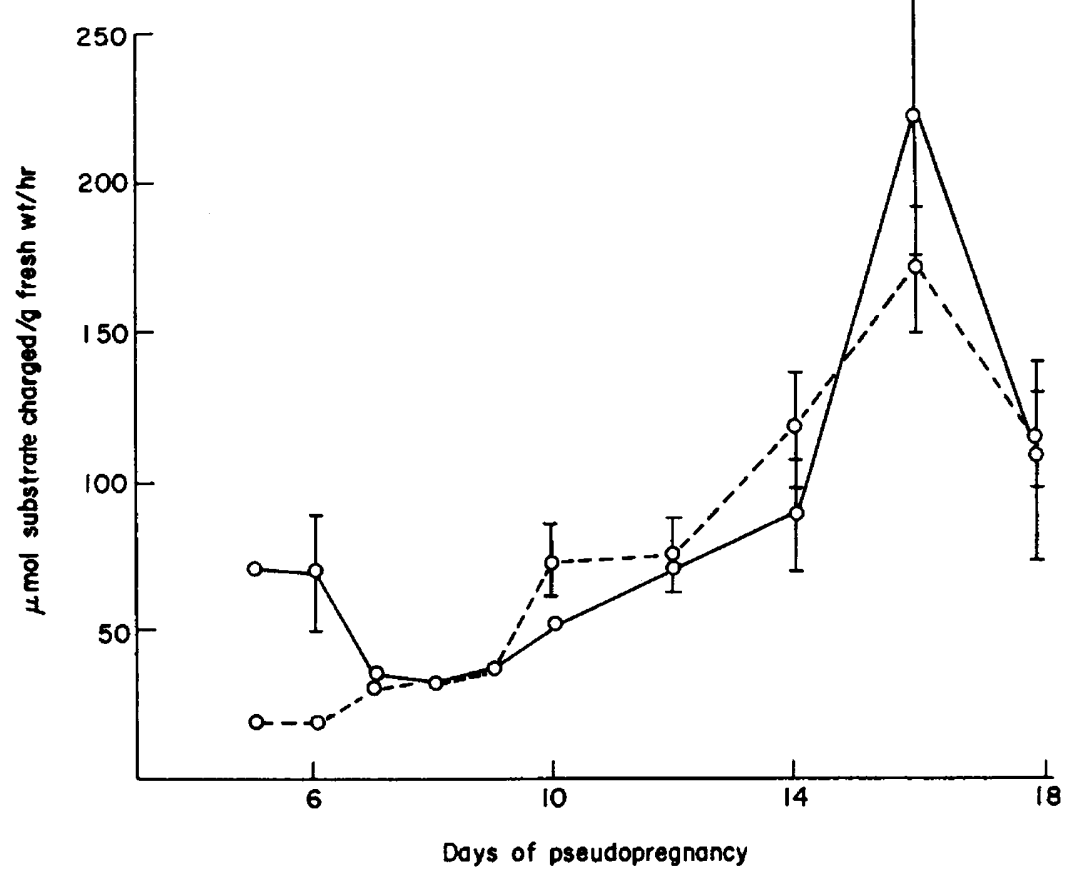

TExT-p1o. 4. Changes in the activity of acid cathepsin $D$ and $\beta$-glucuronidase following uterine trauma during pseudopregnancy. The ordinate gives values of activity for both enzymes. Acid cathepsin D (- $)$; $\beta$-glucuronidase (--- ). 
Acid phosphatase activity increased linearly from Day 5 to Day 10, reached a maximum value on Day 12 and decreased thereafter (Text-fig. 3). Its activity, therefore, rises in forming deciduomata and falls during regression, in contrast to the other lysosomal enzymes which were studied.

The activity of acid cathepsin $D$ in decidual tissue on Day 5 was much lower than that in the control side (Text-fig. 4). It fell further until Day 8, after which there was a slow rise. During the period of regression, there was a marked increase in cathepsin activity which reached a maximum value on Day 16 . The activity of $\beta$-glucuronidase followed a similar pattern. Initially, the activity in the decidual tissue was much lower than that of the control side. Following Day 8, this enzyme also showed a rise in activity which reached a peak on Day 16.

The concentration of mucopolysaccharides rose rapidly to a maximum value on Day 9, fell sharply on Day 10 and decreased further as regression proceeded (Text-fig. 5).

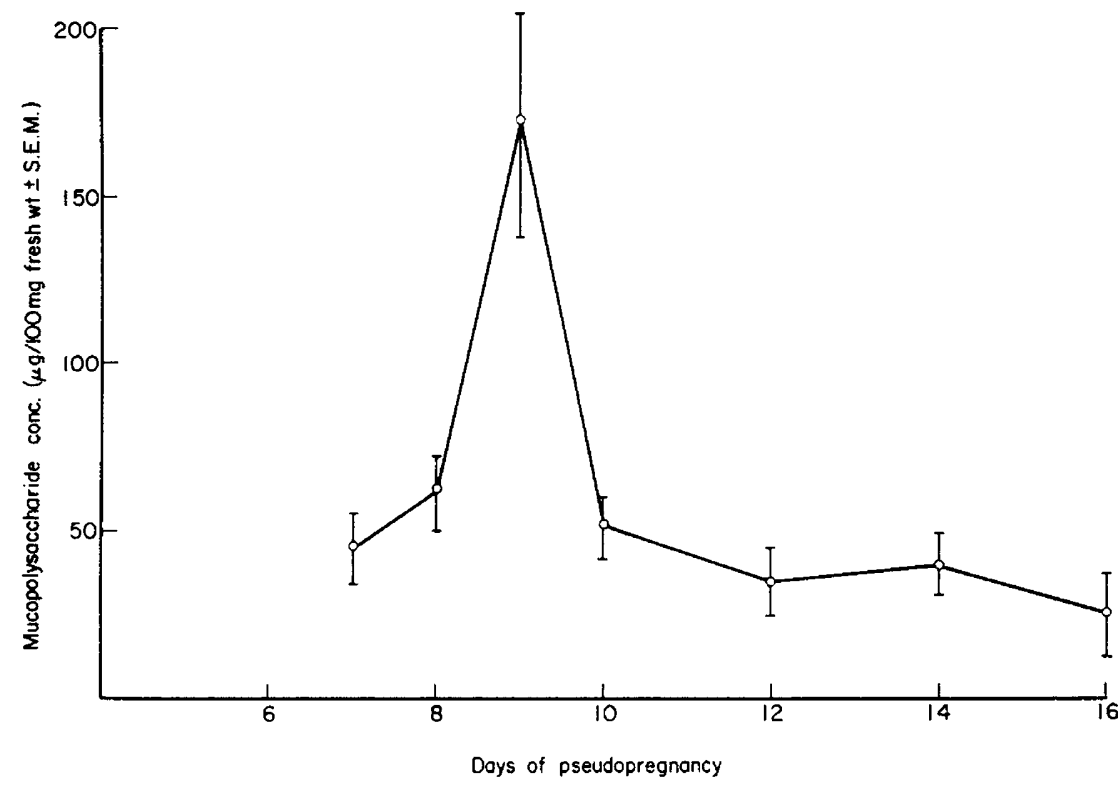

TEXT-pra. 5. Changes in mucopolysaccharide concentration $(\mu \mathrm{g} / 100 \mathrm{mg}$ fresh weight \pm S.E.M.) in rat deciduomata between Days 7 and 16 of pseudopregnancy.

\section{DISCUSSION}

The results reported here suggest that at least two lysosomal enzymes, acid cathepsin $\mathrm{D}$ and $\beta$-glucuronidase, are concerned in the regression of decidual tissue. Acid cathepsin $D$ is probably involved in the breakdown of collagen (Woessner, 1965) and $\beta$-glucuronidase is thought to be responsible for the final stages of degradation of mucopolysaccharides (Conchie \& Findlay, 1959; Levvy \& Marsh, 1959). It therefore seems likely that the rise in activity of these two enzymes is at least partially responsible for the breakdown of two important components in the connective tissue matrix of the deciduoma. 
This idea receives support from the observation that early in pseudopregnancy, when decidual tissue is forming, the activities of these two enzymes are at their lowest level. The preliminary results of changes in mucopolysaccharide concentration during pseudopregnancy, despite the range of variation encountered, correlate well with the observed change in $\beta$-glucuronidase activity. The low activity of this enzyme in the forming deciduoma is probably associated with the rapid accumulation of mucopolysaccharides. The rise in activity between Days 9 and 10 corresponds to the rapid loss of this material, even before there is histological evidence of autolysis. After Day 10, the mucopolysaccharide concentration continues to fall as the activity of $\beta$-glucuronidase rises. Likewise, the rise in cathepsin activity during decidual regression is probably responsible for a loss of collagen. Although no collagen determinations were carried out during this study, it seems reasonable to assume that the low level of this enzyme during deciduomal formation is associated with a synthesis of collagen in the connective tissue matrix of the decidual mass.

It is perhaps surprising that the activity of acid phosphatase increases in forming deciduomata and decreases during regression. Acid phosphatase is frequently used as a marker for lysosomes in histochemical studies (de Duve, 1969), and Lobel, Tic \& Shelesnyak (1965) reported that its activity "remained high during the period of regression and subsequently declined". Meyer (1952) also stated that the activity of acid phosphatase rose from Days 12 to 16 during deciduomal regression. Unfortunately, quantitative details of this work were not published. So far, there is no clear explanation of the discrepancy observed between results reported here and those of other authors in the pattern of acid phosphatase activity, nor is it clear why acid phosphatase should show a change in activity so markedly different from that of the other two lysosomal enzymes. The difference may be due to the fact that some acid phosphatase activity is found in regions of the cell other than the lysosomes. Alternatively, it is possible that lysosomes are a heterogeneous group of subcellular particles and that different particles contain different enzymes, or the same enzymes in differing proportions.

\section{AGKNOWLEDGMENTS}

This work was supported by a grant from the Medical Research Council, London.

\section{REFERENCES}

BrTter, T. \& MuIR, H. M. (1962) A modified uronic acid carbazole reaction. Analyt. Biochem. 4, 330. ConchiE, J. \& FindLAY, J. (1959) Influence of gonadectomy, sex hormones and other factors on the activity of certain glycosidases in the rat and mouse. F. Endocr. 18, 132.

DE Duve, G. (1969) The lysosome in retrospect. In: Lysosomes in Biology and Pathology, Vol. 1, p. 3. Eds. J. T. Dingle and H. B. Fell. North Holland, Amsterdam.

Finn, C. A. \& MaLAREN, A. (1967) A study of the early stages of implantation in mice. F. Reprod. Fert. 13, 259.

Levvy, G. A. \& Marsh, C. A. (1959) Preparation and properties of $\beta$-glucuronidase. Adv. Carbohyd. Chem. 14, 381.

Lobel, B. L., Tic, L. \& Shelesnyak, M. C. (1965) Studies on the mechanism of nidation. XVII. Histochemical analysis of decidualization in rat. Acta endocr., Copenh. 50, 452.

Lowry, O. H., Rosebrough, N.J., FArR, A. L. \& Randali, R. J. (1951) Protein measurement with the Folin phenol reagent. F. biol. Chem. 193, 265. 
Manley, G. \& Mullinger, R. N. (1967) Mucopolysaccharides of atherosclerotic plaques and platelets. Br. F. exp. Path. 48, 529.

Meyer, R. K. (1952) Enzymes in the placentoma of the rat. Ciba Fdn Colloq. Endocr. 1, 266.

Talalay, P., Fishman, W. H. \& Huggins, C. (1946) Chromogenic substrates. II. Phenolphthalein glucuronic acid as substrate for the assay of glucuronidase activity. 7 . biol. Chem. 166, 757.

Woessner, J. F., JR (1965) Acid hydrolases of the rat uterus in relation to pregnancy, post-partum involution and collagen breakdown. Biochem. 7. 97, 855.

WoEssner, J. F., JR \& BREWER, T. H. (1963) Formation and breakdown of collagen and elastin in the human uterus during pregnancy and post-partum involution. Biochem. F. 89, 75. 